\title{
Nitrogen fixation within the water column associated with two hypoxic basins in the Southern California Bight
}

\author{
M. Robert Hamersley ${ }^{1, *}$, K. A. Turk ${ }^{2}$, A. Leinweber ${ }^{3}$, N. Gruber ${ }^{3,4}$, J. P. Zehr ${ }^{2}$, \\ T. Gunderson ${ }^{5}$, D. G. Capone ${ }^{5}$ \\ ${ }^{1}$ Soka University of America, 1 University Dr., Aliso Viejo, California 92656, USA \\ ${ }^{2}$ Ocean Sciences Department, University of California, Santa Cruz, California 95064, USA \\ ${ }^{3}$ Institute of Geophysics and Planetary Physics, University of California Los Angeles, Los Angeles, California 90965, USA \\ ${ }^{4}$ Environmental Physics, Institute of Biogeochemistry and Pollutant Dynamics, ETH Zürich, 8092 Zürich, Switzerland \\ ${ }^{5}$ Wrigley Institute for Environmental Studies, University of Southern California, Los Angeles, California 90089, USA
}

\begin{abstract}
We measured pelagic dinitrogen $\left(\mathrm{N}_{2}\right)$ fixation by incorporation of ${ }^{15} \mathrm{~N}_{2}$ during regular cruises over 4 yr to deep hypoxic basins in the Southern California Bight, USA. $\mathrm{N}_{2}$ fixation in the photic zone was dominated $(80 \%)$ by nanoplankton $(<10 \mu \mathrm{m}) . \mathrm{N}_{2}$ fixation rates in surface waters were near the upper range measured for nanoplankton in tropical waters, averaging $5.8 \mu \mathrm{mol} \mathrm{m}^{-3} \mathrm{~d}^{-1}$ at the San Pedro Ocean Time Series (SPOTS) station, and $2.4 \mu \mathrm{mol} \mathrm{m} \mathrm{m}^{-3} \mathrm{~d}^{-1}$ at the Santa Monica Bay Observatory (SMBO) station, with a maximum at SPOTS of $35 \mu \mathrm{mol} \mathrm{m} \mathrm{m}^{-3} \mathrm{~d}^{-1}$. Quantitative polymerase chain reaction (qPCR) assays and nested PCR-based clone libraries targeting the nitrogenase gene nifH indicate that the uncultivated unicellular cyanobacterial group A (UCYN-A) is an abundant diazotroph in the photic zone. Although $\mathrm{N}_{2}$ fixation rates were highest at the surface, mean $\mathrm{N}_{2}$ fixation averaged $0.07 \mu \mathrm{mol} \mathrm{m} \mathrm{m}^{-3} \mathrm{~d}^{-1}$ at depths of 500 and $885 \mathrm{~m}$ within hypoxic basin waters $\left(<10 \% \mathrm{O}_{2}\right.$ saturation). When integrated over the aphotic water column, this deep $\mathrm{N}_{2}$ fixation may account for as much as one-third of the total areal $\mathrm{N}_{2}$ fixation, estimated at $150 \mu \mathrm{mol} \mathrm{N} \mathrm{m}{ }^{-2} \mathrm{~d}^{-1}$. These deep hypoxic $\mathrm{N}_{2}$ fixers were an assemblage of heterotrophic bacteria, including Alpha- and Gammaproteobacteria and putative sulfate-reducing bacteria. Our results suggest that $\mathrm{N}_{2}$ fixation could play a role in other hypoxic, high-nitrate waters.
\end{abstract}

KEY WORDS: Nitrogen fixation · Diazotrophy $\cdot$ Southern California Bight · Hypoxic basin Resale or republication not permitted without written consent of the publisher

\section{INTRODUCTION}

The inventory of bioavailable (fixed) nitrogen $(\mathrm{N})$ in the ocean is largely regulated by nitrogen fixation, denitrification, and anaerobic ammonium oxidation (anammox)-microbial processes that mediate exchanges with the dominant dinitrogen $\left(\mathrm{N}_{2}\right)$ pool. The consistency of atmospheric carbon dioxide $\left(\mathrm{CO}_{2}\right)$ levels over the last 10000 yr does not support large-scale changes in the inventory of fixed $\mathrm{N}$, suggesting that $\mathrm{N}_{2}$-fixing and $\mathrm{N}_{2}$-producing processes may be tightly coupled via negative feedbacks (Gruber \& Sarmiento 1997, Deutsch et al. 2001, Karl et al. 2002, Gruber 2004). Others have suggested that the sources and sinks of marine $\mathrm{N}$ may not be in balance over glacial-interglacial time scales or that high anthropogenic $\mathrm{N}_{2}$ fixation might have unbalanced the anthropocene (e.g. the post-industrial) N cycle (discussed in Codispoti et al. 2001, Gruber 2004, Codispoti 2007). One proposed mechanism that could regulate the balance between denitrification and $\mathrm{N}_{2}$ fixation is the suggestion that diazotrophs may be able to out- 
compete other phytoplankton when nitrate $\left(\mathrm{NO}_{3}{ }^{-}\right)$concentrations are limiting, a condition that could be exacerbated by denitrification (Karl et al. 2002). However, experimental work demonstrates that $\mathrm{N}_{2}$ fixation can still take place even at relatively high $\mathrm{NO}_{3}{ }^{-}$concentrations (Mulholland et al. 2001, Holl \& Montoya 2005).

Despite the assertion that sources and sinks of $\mathrm{N}$ to the ocean must be in balance, most scaled estimates of marine $\mathrm{N}$ sinks greatly exceed estimated sources (Codispoti et al. 2001, Galloway et al. 2004, Gruber 2004, Codispoti 2007). In the effort to address this imbalance, nitrogen fixation, the largest $\mathrm{N}$ source term, has received a great deal of attention, and yet its magnitude is not well constrained (Codispoti et al. 2001). Marine $\mathrm{N}_{2}$ fixation appears to be dominated (ca. $90 \%$ ) by pelagic processes (Codispoti et al. 2001, Galloway et al. 2004). To address problems with scaling point measurements of $\mathrm{N}_{2}$ fixation, geochemical estimates of pelagic $\mathrm{N}_{2}$ fixation have been developed based on observed sub-euphotic deviations in the ratio of dissolved inorganic $\mathrm{N}$ to $\mathrm{P}$ (phosphate, $\mathrm{PO}_{4}{ }^{3-}$ ) relative to that expected from the canonical Redfield ratio $\left(\mathrm{N}: \mathrm{P}=16\right.$; Redfield et al. 1963). One such measure, $\mathrm{N}^{*}$ :

$$
\mathrm{N}^{*}=\left[\mathrm{NO}_{3}{ }^{-}\right]-16\left[\mathrm{PO}_{4}{ }^{3-}\right]+2.9 \mu \mathrm{mol} \mathrm{kg}{ }^{-1}
$$

is a measure of the deviation of the ratio $\left[\mathrm{NO}_{3}{ }^{-}\right]$: $\left[\mathrm{PO}_{4}{ }^{3-}\right]$ expected from the degradation of average plankton organic matter (Gruber \& Sarmiento 1997, Deutsch et al. 2001). The limitation of the tracer $N^{*}$ is that it cannot disentangle the opposing effects of denitrification and $\mathrm{N}_{2}$ fixation on the dissolved N:P ratio. However, a recent approach examines the deviation of assimilative uptake of $\mathrm{PO}_{4}{ }^{3-}$ relative to the expected $\mathrm{NO}_{3}{ }^{-}$uptake, via changes in the parameter $\mathrm{P}^{*}$ :

$$
\mathrm{P}^{*}=\left[\mathrm{PO}_{4}{ }^{3-}\right]-\left[\mathrm{NO}_{3}{ }^{-}\right] / 16
$$

from which Deutsch et al. (2007) estimated a global pelagic $\mathrm{N}_{2}$ fixation rate of ca. $140 \mathrm{Tg} \mathrm{yr}^{-1}$. In contrast, extrapolations of incubation-based measures of known $\mathrm{N}_{2}$-fixing organisms can account for only ca. $90 \mathrm{Tg} \mathrm{yr}^{-1}$ (Galloway et al. 2004). These estimates have been based on measures of the conspicuous colonial planktonic non-heterocystous cyanobacterium Trichodesmium (Capone et al. 1997, 2005), until recently assumed to be the most significant known contributor to pelagic $\mathrm{N}_{2}$ fixation. Trichodesmium plays the greatest role in tropical oligotrophic surface waters with temperatures $>25^{\circ} \mathrm{C}$, but in recent years, other significant contributors to pelagic $\mathrm{N}_{2}$ fixation have been discovered. The recovery of nifH transcripts related to unicellular cyanobacteria (Zehr et al. 2001, Moisander et al. 2010) as well as the detection of $\mathrm{N}_{2}$ fixation associated with the $<10 \mu \mathrm{m}$ size class of ocean plankton using the ${ }^{15} \mathrm{~N}_{2}$ incorporation technique (Montoya et al. 2004) has highlighted the importance of unicellular nanoplankton in pelagic $\mathrm{N}_{2}$ fixation. Further, the importance of $\mathrm{N}_{2}$ fixation in subtropical and temperate waters with surface temperatures $<20^{\circ} \mathrm{C}$ (previously excluded from global $\mathrm{N}$ budgets) is now supported by both geochemical modeling (Deutsch et al. 2007) as well as direct measures (Holl et al. 2007, Needoba et al. 2007, Rees et al. 2009, Moisander et al. 2010).

The shortfall in the marine $\mathrm{N}$ budget, as well as the insufficiency of Trichodesmium alone to account for the geochemically estimated $\mathrm{N}_{2}$ fixation, has led to a renewed search for $\mathrm{N}_{2}$ fixation by previously overlooked planktonic organisms and in previously overlooked ocean provinces. From analysis of the geochemical parameter $\mathrm{P}^{*}$ combined with a general circulation model of the oceans, Deutsch et al. (2007) suggested that regions of denitrification and $\mathrm{N}_{2}$ fixation in the oceans might be coupled, with some of the highest rates of $\mathrm{N}_{2}$ fixation predicted to coincide with surface waters affected by the oxygen minimum zones (OMZs) of the Pacific and Indian oceans, which are important sites for denitrification and/or anammox (Hamersley et al. 2007). The proximity of $\mathrm{N}_{2}$ fixation and denitrification zones suggests the possibility of coupling and a regulation of $\mathrm{N}_{2}$ fixation by the dissolved N:P ratio (Deutsch et al. 2007).

In the present study, we examined $\mathrm{N}_{2}$ fixation in the waters adjacent to 2 hypoxic basins in the Southern California Bight. The California Undercurrent transports water bearing the signature of OMZ denitrification $\left(\mathrm{N}^{*}<0\right)$ from the eastern tropical North Pacific northward (Codispoti \& Richards 1976). Restricted circulation within the basins of the Southern California Bight results in varying degrees of water column hypoxia below the sill depth (Berelson 1991). Upwelling events transport nitrate-rich deep water into the mixed-layer, resulting in periodic algal blooms (Nezlin \& Li 2003). Sea surface temperatures (SST) peak up to $22^{\circ} \mathrm{C}$ in the summer, but fall to ca. $14^{\circ} \mathrm{C}$ during the winter months (Nezlin \& Li 2003).

We measured $\mathrm{N}_{2}$ fixation via incorporation of ${ }^{15} \mathrm{~N}_{2}$ during regular cruises to the waters adjacent to the San Pedro and Santa Monica Basins, near Los Angeles, California $\left(34^{\circ} \mathrm{N}\right.$ latitude), USA. In the San Pedro Basin, we incubated whole water, size-fractionated particulates by filtration at assay termination, and made measurements in the photic zone as well as deep within the aphotic hypoxic zone. We also characterized the abundance and diversity of the nitrogenase nifH gene in the water column through quantitative PCR (qPCR) and construction of nifH clone libraries. In the surface waters of Santa Monica Bay, we measured $\mathrm{N}_{2}$ fixation using trace-metal-clean approaches to study the sensitivity of $\mathrm{N}_{2}$ fixation to small additions of iron or phosphate. 


\section{MATERIALS AND METHODS}

Site description and field sampling. We measured hydrographic and chemical profiles and $\mathrm{N}_{2}$ fixation rates during cruises to 2 sites in the Southern California Bight near Los Angeles, USA. The San Pedro Ocean Time Series (SPOTS) station, near the center of the $900 \mathrm{~m}$ deep San Pedro Basin (Fig. 1), was monitored from 14 July 2004 to 13 September 2006 from the RV 'Sea Watch' (Southern California Marine Institute). Hydrographic and chemical profiles were measured on 26 cruises, and $\mathrm{N}_{2}$ fixation was measured during 15 of these. Nitrogen fixation at SPOTS was measured at the surface, chlorophyll maximum (range 16 to $37 \mathrm{~m}$ ), $500 \mathrm{~m}$, and $885 \mathrm{~m}$ (ca. $1.5 \mathrm{~m}$ from bottom). The Santa Monica Bay Observatory (SMBO) station, a site $470 \mathrm{~m}$ deep on the margin of the Santa Monica Basin (Fig. 1), was monitored from 11 July 2006 to 7 July 2007 from the RV 'Seaworld' (University of California, Los Angeles, UCLA). Hydrographic and chemical profiles were measured during 25 cruises, and $\mathrm{N}_{2}$ and $\mathrm{C}$ fixation were measured on 8 of these cruises. All reported errors are standard errors (SE).

Hydrographic and chemical measurements. Hydrographic measurements and water samples at SPOTS were collected using a CTD-rosette equipped with 12 Niskin bottles, a Seabird 911 plus CTD with a model 13 oxygen sensor, and a Seapoint chlorophyll fluorometer. In situ measurements were calibrated with Winkler titrations (oxygen) and fluorometric measurements of

$\mathrm{m}$ below $\mathrm{SL}$

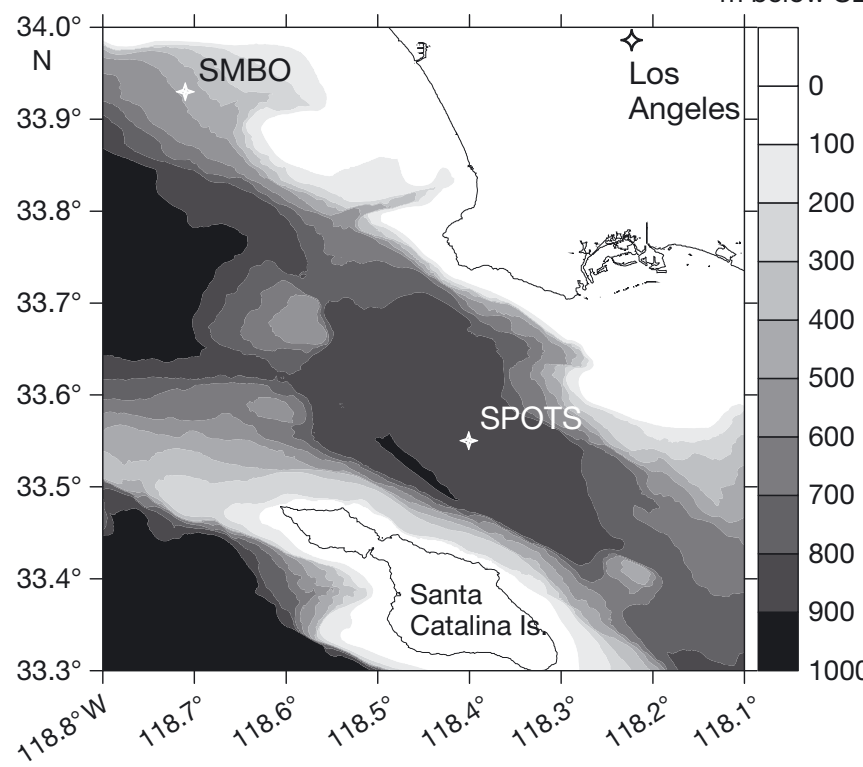

Fig. 1. Bathymetry and location of the 2 sampling stations in the Southern California Bight, USA. SPOTS = San Pedro Ocean Time Series site in the San Pedro Basin. SMBO = Santa Monica Bay Observatory site at the edge of the Santa Monica Basin. SL: sea level extracted chlorophyll a (chl a) (Grasshoff et al. 1999) in bottle samples collected at 12 depths throughout the water column. We also identified the diazotrophs present in the photic and aphotic zones on 1 date using the qPCR for the nitrogenase gene nifH, as well as generating clone libraries using nested nifH PCR. Hydrographic measurements at SMBO were made with a Seabird 19 plus CTD. Water samples were collected at 6 to 12 depths by Niskin bottle. Nitrate and phosphate were analyzed colorimetrically by autoanalysis (Technicon AAII, detection limit $0.1 \mu_{\mathrm{mol} \mathrm{l}} \mathrm{l}^{-1}$ ) (Grasshoff et al. 1999). $\mathrm{N}^{*}$ was calculated after Deutsch et al. (2001) (Eq. 1).

Nitrogen and carbon fixation. Nitrogen fixation was determined using the ${ }^{15} \mathrm{~N}_{2}$ incorporation technique (Montoya et al. 2004). Briefly, polycarbonate bottles (4 1 at SPOTS, 2.51 at SMBO) were filled with water collected in Niskin bottles during CTD casts. Water collected from hypoxic depths at SPOTS (500 and $885 \mathrm{~m}$ ) was introduced by tubing into the bottom of argonfilled bottles to minimize aeration. Bottles were immediately capped with septa, and trace additions of ${ }^{15} \mathrm{~N}_{2}$ (98 atom\%, Sigma-Aldrich/Isotec $;{ }^{15} \mathrm{~N}_{2}<1 \%$ of background $\mathrm{N}_{2}$ ) were introduced through the septum via a gas-tight syringe. Bottles with water from the surface and chlorophyll-maximum depths were incubated in triplicate or quadruplicate in running sea water under ambient light. Chlorophyll-maximum bottles were shaded with mesh screen to simulate in situ light levels (ca. $1 \%$ of surface). Incubations of water from the 500 and $885 \mathrm{~m}$ depths were carried out in duplicate in the dark at $5^{\circ} \mathrm{C}$. Background $\delta^{15} \mathrm{~N}$ and $\delta^{13} \mathrm{C}$ of particulate matter were determined on samples collected simultaneously. Duplicate unamended controls were incubated as described above and size-fractionated/filtered as described below; no significant change in the $\delta^{15} \mathrm{~N}$ and $\delta^{13} \mathrm{C}$ of particulate matter was observed after $24 \mathrm{~h}$ incubation. The contents of additional duplicate bottles were filtered immediately after adding ${ }^{15} \mathrm{~N}_{2}$ (SPOTS and $\mathrm{SMBO}$ ) and $\mathrm{H}^{13} \mathrm{CO}_{3}{ }^{2-}$ (SMBO) as time zero controls. No significant change in $\delta^{15} \mathrm{~N}$ of particulate matter was seen immediately after tracer injection, and changes in $\delta^{13} \mathrm{C}$ were as expected from the necessary delay between tracer addition and filtration. Incubations (24 h) were ended by size-fractionation/filtration through Nuclepore prefilters (Whatman) of poresize $10 \mu \mathrm{m}$ followed by precombusted GF/F filters (poresize $0.7 \mu \mathrm{m}$, Whatman), or, on some dates, through GF/F filters alone. Seston collected on filters of poresize $10 \mu \mathrm{m}$ was washed with deionized water (DI) onto GF/F filters in preparation for mass spectrometric analysis. $\mathrm{GF} / \mathrm{F}$ filters were dried for $24 \mathrm{~h}$ at $60^{\circ} \mathrm{C}$. Mass spectrometric analysis was performed on an elemental analyzer-isotope ratio mass spectrometer (SerCon Integra, University of California, Davis Stable Isotope Facility). 
At SMBO, carbon fixation was determined as the incorporation, over $24 \mathrm{~h}$, of added ${ }^{13} \mathrm{C}$-bicarbonate into particulate carbon. ${ }^{13} \mathrm{C}$-bicarbonate was added as $\mathrm{NaH}^{13} \mathrm{CO}_{3}$ to a final concentration of $21 \mu \mathrm{mol} \mathrm{l}{ }^{-1}$, ca. $1 \%$ of the mean dissolved inorganic carbon (DIC) background concentration of $1980 \mu \mathrm{mol} \mathrm{l}^{-1}$ (see 'Results' below). The ${ }^{13} \mathrm{C}$-bicarbonate solution was first passed through a Chelex (Sigma-Aldrich) column to strip out any metal contaminants. Water samples for DIC and alkalinity determination were drawn from Niskin samplers into clean 0.3 l glass bottles, using established gas sampling protocols (Dickson \& Goyet 1994), at around 09:30 to 11:00 h local time; DIC was determined immediately after sampling in the UCLA laboratory using the coulometric SOMMA system (Johnson et al. 1993), and alkalinity was determined by open-cell potentiometric titration (Dickson \& Goyet 1994).

Molecular analysis. Samples for molecular analysis at the SPOTS station were collected and filtered as described in Goebel et al. (2010) on 27 April 2010. Filters collected for ribonucleic acid (RNA) extraction were placed in RLT buffer (Qiagen) containing $\beta$-mercaptoethanol prior to flash freezing. All filters were stored at $-80^{\circ} \mathrm{C}$ until extraction. Deoxyribonucleic acid (DNA) was extracted from both $10 \mu \mathrm{m}$ and GF/F filters using freezethaw cycles, bead-beating, proteinase $\mathrm{K}$ treatment, and ribonuclease A digestion as described in Moisander et al. (2008) with modifications. After removal of the filter and centrifugation (5 min at $14000 \mathrm{rpm}, 18000 \times \mathrm{g}$ ), the final steps of extraction were automated using a QIAcube and the DNeasy Plant mini kit (Qiagen). DNA extracts were stored at $-20^{\circ} \mathrm{C}$.

Nested PCR amplification for nifH was carried out on DNA extracts using nifH3/nifH4 and nifH1/nifH2 primers as described in Foster et al. (2009a). Prior to cloning, PCR products were gel-purified using the Qiaquick gel extraction kit (Qiagen). NifH amplicons were ligated into a pGEM-T vector (Promega) and cloned according to manufacturer's guidelines. Clones were selected randomly and plasmids were extracted using a Montage Plasmid MiniPrep 96 kit (Millipore) then sequenced using the Sanger method at the DNA Sequencing Facility of the University of California, Berkeley. Sequences were quality-trimmed, and vector sequences were removed using Sequencher 4.10.1 software (Gene Codes). Neighbor-joining trees were constructed in ARB (Technical University of Munich) using a publicly-available nifH database (Zehr et al. 2003), and bootstrapped in MEGA 4.0 (Tamura et al. 2007). Like sequences were binned into phylotypes using a $97 \%$ amino-acid sequence similarity cut-off using DOTUR (Schloss \& Handelsman 2005). All sequences were submitted to Genbank under accession numbers HQ660812 to HQ660942.
The abundance of cyanobacterial and proteobacterial diazotrophs was quantified in DNA extracts using Taqman ${ }^{\circledR}$ nifH qPCR assays. The uncultivated unicellular cyanobacterial group A (UCYN-A) and Trichodesmium spp. were quantified using the primers and probes described in Church et al. (2005a). Crocosphaera-like group B (UCYN-B) was quantified as in Moisander et al. (2010). NifH from the symbiont Richelia, associated with 2 hosts - Rhizosolenia clevii (RR) and Hemiaulus hauckii (HR) - was quantified using the primers and probes described in Church et al. (2005b) and Foster et al. (2009b), respectively. The proteobacterial diazotrophs, $\gamma$-24774A11 and $\alpha$ 24809A06, were quantified as in Moisander et al. (2008). All qPCR assays were conducted as described in Moisander et al. (2010), and each sample was screened for inhibition according to Goebel et al. (2010). Samples where amplification was observed but was below the limit of quantification (8 nifH copies per reaction) were designated 'detected not quantified' (DNQ).

Trace nutrient additions. At SMBO, water samples were collected and incubations were made under tracemetal-clean conditions, as described by Mendez (2008). Briefly, water samples for incubations and nutrient measurements were collected using acid-washed Niskin bottles with Teflon-coated external springs and messengers, deployed on a $1 / 4$-inch (ca. $6 \mathrm{~mm}$ ) polyester line from a polyvinylchloride-coated winch. Niskin bottles were rinsed with sea water before use and with DI after use. All bottles or plasticware coming into contact with seawater or amendment solutions were leached for $1 \mathrm{wk}$ in $10 \% \mathrm{HCl}$, followed by $1 \mathrm{wk}$ in $1 \%$ Ultratrace $\mathrm{HCl}$, followed by a further period of $1 \mathrm{wk}$ in DI to neutralize $\mathrm{pH}$. Incubation bottles were filled on board ship via a hose running from the Niskin bottles to a metalfree laminar flow hood equipped with a high-efficiency particle air filter. ${ }^{13} \mathrm{C}$-bicarbonate, and iron or phosphate amendments, were added to the incubation bottles under the laminar flow hood before they were capped with septa. Phosphate was added as a $\mathrm{KH}_{2} \mathrm{PO}_{4}$ solution to a final concentration of $0.43 \mu \mathrm{mol} \mathrm{l^{-1 }}$, a ca. $160 \%$ increase over the mean background concentration of $0.26 \mu \mathrm{mol} \mathrm{l}^{-1}$ (see 'Results' below). Iron was added as a solution of $\mathrm{FeSO}_{4}$ in $\mathrm{HCl}(\mathrm{pH}=2)$ to maintain solubility. Iron was added to a final concentration of $3.4 \mathrm{nM}$, а ca. $190 \%$ increase over the mean background level of $1.8 \mathrm{nM}$ (Mendez 2008) (see 'Results' below). Measurements of total iron concentrations within bottles before and after the $24 \mathrm{~h}$ incubations showed no significant change (Inductively Coupled Plasma Mass Spectrometry, ICP-MS; S. Sañudo-Wilhelmy [University of Southern California, USC] pers. comm.; data not shown). After capping, the bottles were incubated and filtered as described in 'Nitrogen and carbon fixation'. 


\section{RESULTS}

\section{SPOTS site}

The SPOTS site in the San Pedro Basin has a water column characterized by summer thermal stratification, with SST ranging annually from $12^{\circ}$ to $23^{\circ} \mathrm{C}$ (Fig. 2A). The basin is hypoxic $\left(<10 \% \mathrm{O}_{2}\right.$ saturation) below ca. $500 \mathrm{~m}$ (Fig. 2D), with a mean bottom-water dissolved $\mathrm{O}_{2}$ concentration of $11 \pm 3 \mu \mathrm{mol} \mathrm{l}^{-1}$ and a temperature of 5.2 $\pm 0.0^{\circ} \mathrm{C}$. In May and June of 2006, a basin-flushing event (Berelson 1991) introduced oxygenated waters into the
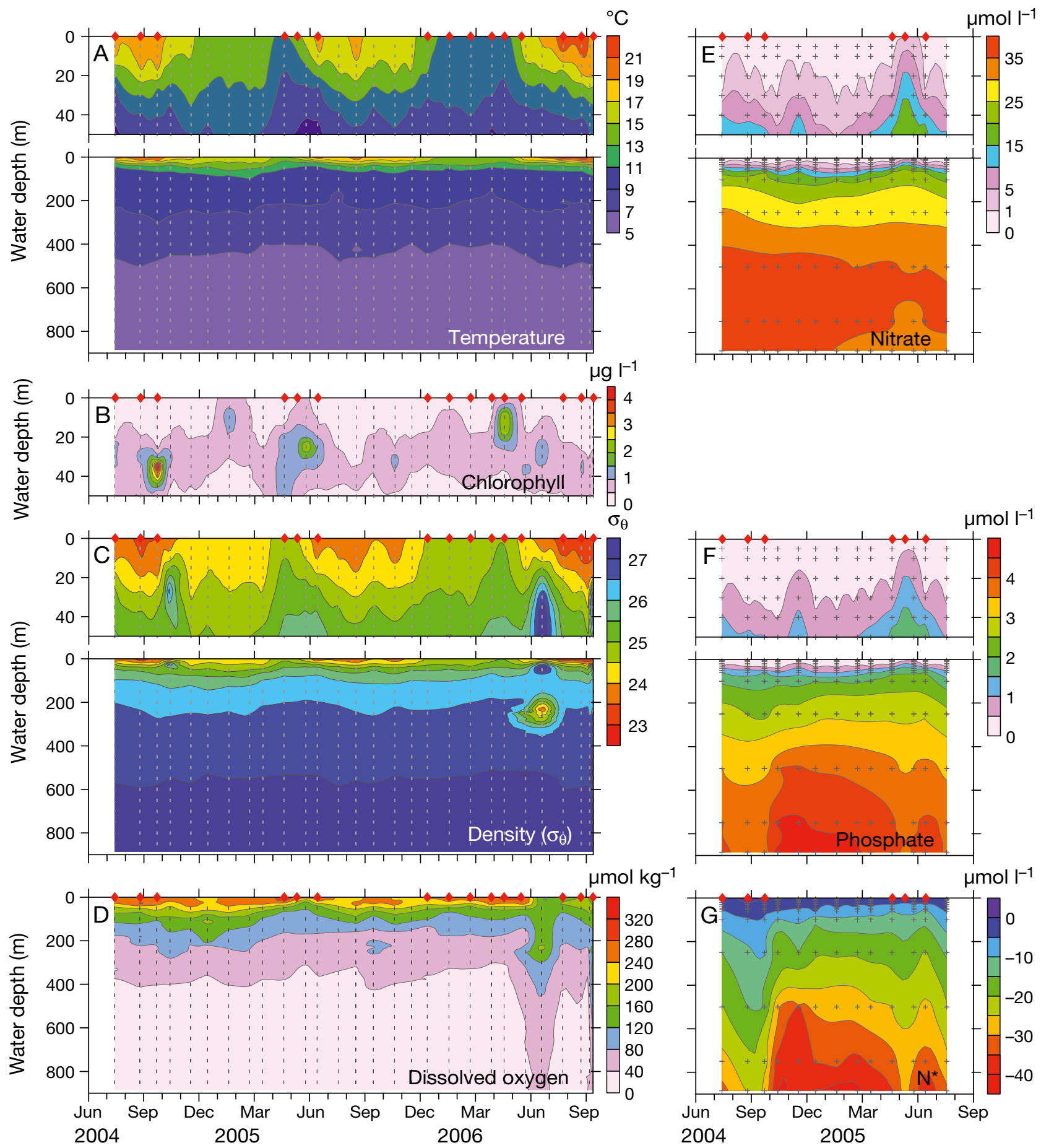

Fig. 2. Hydrographic and chemical properties over a 1- to 2-yr period at SPOTS (see Fig. 1 legend). (A) temperature $\left({ }^{\circ} \mathrm{C}\right) ;(\mathrm{B})$ chlorophyll a $\left(\mu \mathrm{g} \mathrm{l}^{-1}\right)$; (C) potential density $\left(\sigma_{\theta}\right)$; (D) dissolved oxygen $\left.(\mu \mathrm{mol} \mathrm{kg})^{-1}\right)$; (E) nitrate $\left(\mu m o l \mathrm{l}^{-1}\right)$; $(\mathrm{F})$ phosphate $\left(\mu \mathrm{mol} \mathrm{l^{-1 }}\right)$; and $(\mathrm{G}) \mathrm{N}^{*}\left(\mu \mathrm{mol} \mathrm{l^{-1 }}\right)$. The upper $50 \mathrm{~m}$ of the water column is shown in an expanded $y$-axis scale in some of the panels. Sampling dates of continuous profiles are indicated by vertical dashes, while discrete Niskin bottle samples are indicated by crosses. Red diamonds indicate dates of $\mathrm{N}_{2}$ fixation incubations 
basin (Fig. 2D). Surface waters were depleted in nutrients relative to subsurface waters, particularly during stratification, with mean nitrate and phosphate concentrations during the study period of $0.2 \pm 0.0$ and $0.3 \pm$ $0.0 \mu \mathrm{mol} \mathrm{l}^{-1}$ (maximum 0.4 and $0.4 \mu \mathrm{mol} \mathrm{l}^{-1}$ ), respectively (Fig. 2E,F). The depth of maximum chl a concentrations ranged from 16 to $37 \mathrm{~m}$, deeper during the summer and shallower in the winter (Fig. 2B). A number of algal blooms were observed, primarily in the spring. $\mathrm{N}^{*}$ was negative throughout the water column, indicating the influence of net denitrification on these waters (Fig. 2G).

Nitrogen fixation rates at SPOTS were highest at the surface (mean $5.8 \pm 2.6 \mu \mathrm{mol} \mathrm{N} \mathrm{m}{ }^{-3} \mathrm{~d}^{-1}$; range 0.3 to $36.4 \mu \mathrm{mol} \mathrm{N} \mathrm{m}{ }^{-3} \mathrm{~d}^{-1}$ ) (Fig. 3A, Table 1). Nitrogen fixation was dominated by nanoplankton of $<10 \mu \mathrm{m}$ size, which were responsible for $80 \pm 5 \%$ of the measured $\mathrm{N}_{2}$ fixation (Table 1). The highest rates of $\mathrm{N}_{2}$ fixation were measured in December 2005 and February 2006. With the exception of this episode of high winter $\mathrm{N}_{2}$ fixation, the pattern of $\mathrm{N}_{2}$ fixation was significantly and positively correlated with SST (Pearson's product-moment correlation coefficient $=0.54, t_{10}=2.1, p=0.03$ ). Nitrogen fixation at the chlorophyll maximum was considerably lower and less variable, averaging $1.0 \pm 0.3 \mu \mathrm{mol} \mathrm{N}$ $\mathrm{m}^{-3} \mathrm{~d}^{-1}$ (Fig. 3B). Nitrogen fixation was also detected within the hypoxic water column (at 500 and $885 \mathrm{~m}$ ) at the lower mean rate of $0.07 \mu$ mol $\mathrm{N} \mathrm{m}^{-3} \mathrm{~d}^{-1}$ (Table 1, Fig. 3C,D). The contribution of nanoplankton to total $\mathrm{N}_{2}$ fixation was greater within the hypoxic zone $(87 \%$ at $500 \mathrm{~m}$ and $100 \%$ at $885 \mathrm{~m})$ than at the surface $(80 \%)$ or chlorophyll maximum ( $77 \%$ ). However, the $<10 \mu \mathrm{m}$ size fraction contributed only ca. $70 \%$ of the total particulate $\mathrm{N}(\mathrm{PN})$ at the surface and chlorophyll maximum. $\mathrm{N}_{2}$ fixation by the nanoplankton was therefore greater than would be expected by their contribution to standing stocks of PN alone (see Fig. S1 in the supplement at www.int-res.com/articles/suppl/a063p193_supp.pdf).

Both the uncultivated UCYN-A and the heterocystous symbiont Richelia spp. were quantified in the $<10 \mu \mathrm{m}$ fraction within the photic zone using nifH qPCR (Table S1 in the supplement at www.int-res. com/articles/suppl/a063p193_supp.pdf). UCYN-A nifH abundance decreased dramatically below the photic zone, but was detected at all depths. Richelia spp., associated with both Rhizosolenia spp. and Hemiaulus spp., were quantified in the $>10 \mu \mathrm{m}$ fraction at a depth of $45 \mathrm{~m}$ (Table S1). The other cyanobacterial phylotypes, UCYN-B and Trichodesmium, were not detected in any samples. An alphaproteobacterial phylotype, $\alpha$-24809A06, was quantified at low abundance in both size fractions at a depth of $350 \mathrm{~m}$ (Table S1).

$\mathrm{NifH}$ clone libraries were generated from DNA extracts from depths of 5, 750 and $885 \mathrm{~m}$. In the surface samples, only 3 phylotypes were recovered: 2 UCYN-A phylotypes and a gammaproteobacterium closely re-

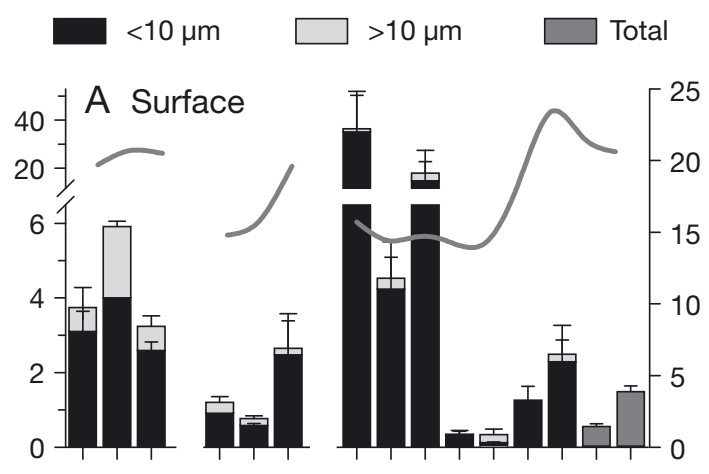

B Chlorophyll maximum
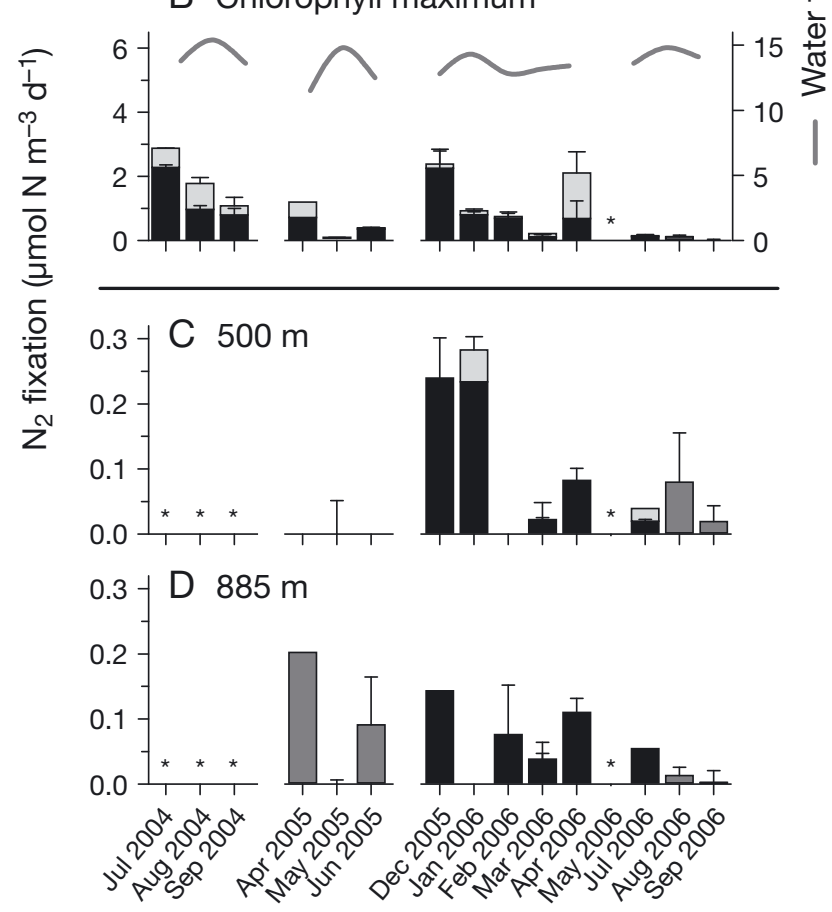

Fig. 3. $\mathrm{N}_{2}$ fixation at SPOTS (see Fig. 1 legend) by particle size fraction at 4 depths: (A) surface $(2.5 \mathrm{~m})$; (B) chlorophyll maxi-

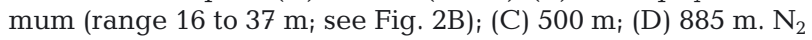
fixation rates for the $<10 \mu \mathrm{m}$ particulate fraction are indicated by black bars, the $>10 \mu \mathrm{m}$ fraction by light gray, and total $\mathrm{N}_{2}$ fixation (unfractionated incubations) by dark gray. Water temperatures are indicated by gray lines in panels A and B. Mean temperatures at $500 \mathrm{~m}$ and $885 \mathrm{~m}$ were 6.6 and $5.2^{\circ} \mathrm{C}$, respectively. Note the differing $y$-axis scales in panels $C$ and D vs. A and B. An asterisk $(*)$ indicates that no data were collected on that date. Error bars are SE

lated to $\gamma$-24774A11 (Fig. 4). The UCYN-A phylotype, SPOTS_45702A2, was the most highly recovered in this study and was found in both size fractions at the surface, as well as at depths of 750 and $885 \mathrm{~m}$. The nifH sequences recovered from the hypoxic water samples were an assemblage of heterotrophs, most of which were recovered only once. Phylotypes belonged primarily to Clusters I and III, but included a single Cluster IV phylotype (Fig. 4). The most highly recovered 
Table 1. Mean particulate $\mathrm{N}$ and $\mathrm{N}_{2}$ fixation at SMBO and SPOTS (see Fig. 1). Measurements at SPOTS are size-fractionated into $<10 \mu \mathrm{m}$ and $>10 \mu \mathrm{m}$ pools. Chl. max. = chlorophyll maximum. SE in parentheses

\begin{tabular}{|c|c|c|c|c|c|}
\hline Site & Depth & Total & $<10 \mu \mathrm{m}$ & $>10 \mu \mathrm{m}$ & $\%<10 \mu \mathrm{m}$ \\
\hline \multicolumn{6}{|c|}{ Particulate $\mathrm{N}\left(\boldsymbol{\mu m o l} \mathrm{l}^{-1}\right)$} \\
\hline SMBO & Surface & $1.6(0.3)$ & & & \\
\hline SPOTS & Surface & $1.1(0.2)$ & $0.86(0.13)$ & $0.39(0.07)$ & $70(3)$ \\
\hline SPOTS & Chl. max. & $2.0(0.8)$ & $1.4(0.5)$ & $0.80(0.38)$ & $67(3)$ \\
\hline SPOTS & $500 \mathrm{~m}$ & $0.23(0.03)$ & $0.12(0.04)$ & $0.10(0.04)$ & $56(16)$ \\
\hline SPOTS & $885 \mathrm{~m}$ & $0.25(0.04)$ & $0.15(0.05)$ & $0.08(0.03)$ & $61(14)$ \\
\hline \multicolumn{6}{|c|}{ 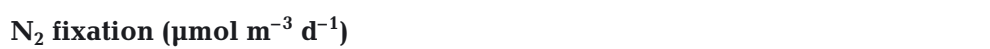 } \\
\hline SMBO & Surface & $2.4(1.6)$ & & & \\
\hline SPOTS & Surface & $5.8(2.6)$ & $5.5(2.7)$ & $0.75(0.27)$ & $0(5)$ \\
\hline SPOTS & Chl. max. & $1.0(0.3)$ & $0.82(0.21)$ & $0.34(0.12)$ & $77(6)$ \\
\hline SPOTS & $500 \mathrm{~m}$ & $0.07(0.03)$ & $0.10(0.04)$ & $0.01(0.01)$ & $87(10)$ \\
\hline SPOTS & $885 \mathrm{~m}$ & $0.07(0.02)$ & $0.08(0.02)$ & $0.00(0.00)$ & $100(0)$ \\
\hline
\end{tabular}

non-cyanobacterial phlyotype, SPOTS_45708A38, accounted for $8 \%$ of all the sequences recovered in this study, and was most closely related to an uncultivated alphaproteobacterium from the South China Sea (GenBank accession no. EU052627; Moisander et al. 2008). SPOTS_45708A198, SPOTS_45712A16 and SPOTS_45706A170 had high amino acid sequence identity with an uncultivated gammaproteobacterium from an intertidal microbial mat (GenBank accession no. AF046847; Olson et al. 1999), and together also accounted for $8 \%$ of all sequences. A number of phylotypes recovered belonged to Cluster III, of which a majority of the cultivated representatives are strict anaerobes. When considered together, Cluster III sequences accounted for nearly a third (26\%) of the sequences recovered from SPOTS. Several of these were closely related to putative sulfate-reducing bacteria (e.g. Cluster 3E sequences, Fig. 4).

\section{SMBO site}

The SMBO site also exhibited summer thermal stratification, although SSTs were slightly lower than at SPOTS $\left(12^{\circ}\right.$ to $21^{\circ} \mathrm{C}$ ) (Fig. 5A). Although this site was at the edge of the Santa Monica Basin (Fig. 1), bottom waters were hypoxic (Fig. 5C). Four distinct chl a blooms were observed in the fall of 2006 (Fig. 5B). Four upwelling events took place during the winter and spring of 2007, as can be seen by the intrusion of denser and cooler water to the surface (Fig. 5A,D). These upwelling events also brought $\mathrm{NO}_{3}{ }^{-}$and $\mathrm{PO}_{4}{ }^{3-}$ to the surface (Fig. 5E,F). As at SPOTS, nitrate and phosphate were usually depleted at the surface (means 0.7 and $0.3 \mu \mathrm{mol} \mathrm{l}^{-1}$ and maxima 10.9 and $1.0 \mu \mathrm{mol} \mathrm{l}^{-1}$, respectively). $\mathrm{N}^{*}$ was also negative, although not as strongly as at SPOTS (Fig. 5G).
$\mathrm{N}_{2}$ fixation at SMBO averaged less than half of that at SPOTS, at $2.4 \pm$ $1.6 \mu \mathrm{mol} \mathrm{N} \mathrm{m} \mathrm{N}^{-3} \mathrm{~d}^{-1}$ (Fig. 6, Table 1). In September 2006, an episode of elevated $\mathrm{N}_{2}$ fixation attained a rate of $14.9 \mu \mathrm{mol} \mathrm{N} \mathrm{m}^{-3} \mathrm{~d}^{-1}$. Carbon fixation at SMBO averaged $6.0 \pm 2.3 \mathrm{mmol}$ $\mathrm{m}^{-3} \mathrm{~d}^{-1}$ (maximum $14.6 \mathrm{mmol} \mathrm{m} \mathrm{m}^{-3} \mathrm{~d}^{-1}$ ), in excellent agreement with the recent partial pressure of carbon dioxide $\left(p \mathrm{CO}_{2}\right)$-based estimate of net primary production $\left(7 \mathrm{mmol} \mathrm{m} \mathrm{m}^{-3} \mathrm{~d}^{-1}\right.$ ) by Leinweber et al. (2009). There was also no significant difference in $\mathrm{N}_{2}$ or $\mathrm{C}$ fixation between control treatments and treatments with added $\mathrm{P}$ or Fe (repeated measures ANOVA; $\mathrm{N}_{2}$ fixation: $F_{2,8}=0.97, \mathrm{p}=0.42 ; \mathrm{C}$ fixation: $F_{2,68}=$ $0.17, \mathrm{p}=0.84$ ) (Fig. $\mathrm{S} 2$ in the supplement at www.intres.com/articles/suppl/a063p193_supp.pdf).

As a preliminary assessment of areal rates of $\mathrm{N}_{2}$ fixation for SPOTS, we divided the water column into a photic zone, which extended from the surface to the chlorophyll maximum, and an aphotic zone, that extended from the chlorophyll maximum to the bottom. Photic zone $\mathrm{N}_{2}$ fixation was estimated as the depth-integrated mean of the measured surface and chlorophyll maximum $\mathrm{N}_{2}$ fixation, while aphotic zone $\mathrm{N}_{2}$ fixation was estimated as the depth-integrated mean of the $\mathrm{N}_{2}$ fixation measurements at $500 \mathrm{~m}$ and $885 \mathrm{~m}$. While we believe that this is a conservative estimate of areal $\mathrm{N}_{2}$ fixation, because it supposes that $\mathrm{N}_{2}$ fixation immediately below the chlorophyll maximum is equal to the much lower $\mathrm{N}_{2}$ fixation rates we measured at $500 \mathrm{~m}$ and $885 \mathrm{~m}$, we acknowledge that the $\mathrm{N}_{2}$ fixation rate between the chlorophyll maximum and a depth of $500 \mathrm{~m}$ is poorly constrained. Estimated in this way, $\mathrm{N}_{2}$ fixation integrated over the entire water column averaged $150 \mu \mathrm{mol} \mathrm{N} \mathrm{m}{ }^{-2} \mathrm{~d}^{-1}$ (maximum $760 \mu \mathrm{mol} \mathrm{N} \mathrm{m}{ }^{-2} \mathrm{~d}^{1}$ ). Although volumetrically, aphotic-zone $\mathrm{N}_{2}$ fixation rates are low relative to the photic zone (Fig. 3), because of its greater vertical extent, the aphotic water column may be responsible for a significant proportion (ca. $50 \%$, or $55 \mu \mathrm{mol} \mathrm{N} \mathrm{m}^{-2} \mathrm{~d}^{-1}$ ) of the photic areal $\mathrm{N}_{2}$ fixation (98 $\mu \mathrm{mol} \mathrm{N} \mathrm{m}^{-2} \mathrm{~d}^{-1}$ ) (Fig. $\mathrm{S} 3$ in the supplement at www.int-res.com/articles/suppl/a063p193_supp.pdf).

\section{DISCUSSION}

\section{Nitrogen fixation by nanoplankton}

We studied $\mathrm{N}_{2}$ fixation over a 4 yr period in waters in, and adjacent to, 2 hypoxic basins in the Southern California Bight. These sites were characterized by nega- 

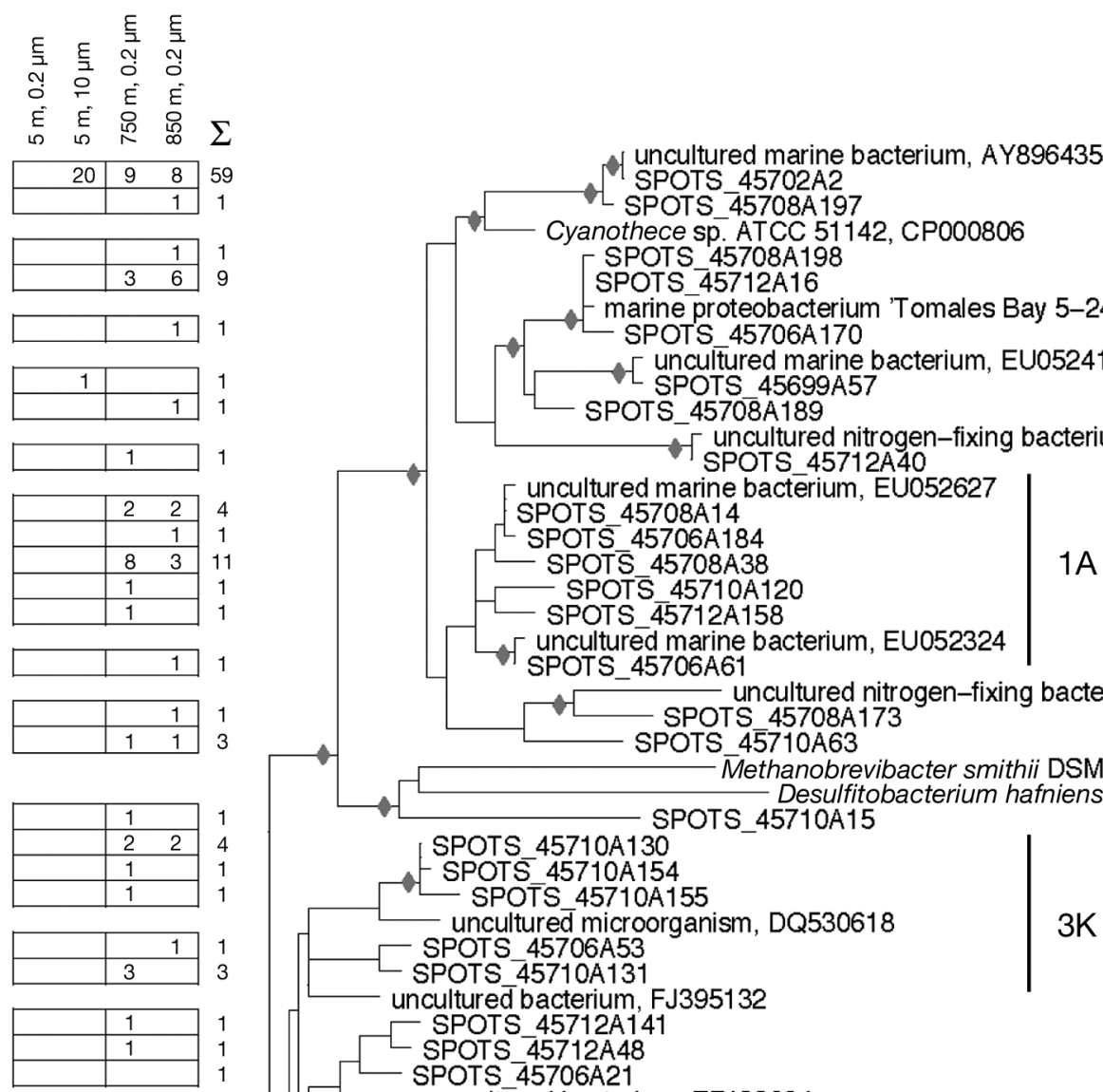
SPOTS 45702A2

- Cyanothece sp. ATCC 51142, CP000806

UCYN-A (1B)

Clusters

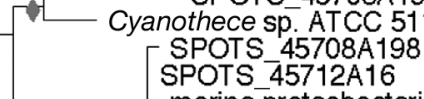

SPOTS_45712A16

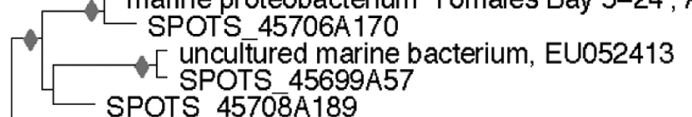

SPOTS 45699 A5

SPOTS 45708A189

uncultured nitrogen-fixing bacterium, EF208186

$\gamma-24774 \mathrm{~A} 11$

SPOTS_45712A40

uncultured marine bacterium, EU052627

SPOTS 45708A14

SPOTS 45706 A184

SPOT $\bar{S}$ 45708A38

SPOTS $45710 A 120$

- SPOTS $45712 A 158$

uncultured marine bacterium, EU052324

SPOTS_45706A61

uncultured nitrogen-fixing bacterium, AY768678

SPOTS 45708 A 173

SPOTS_457710A63

Methanobrevibacter smithii DSM 2375, ABYW01000005 Desulfitobacterium hafniense Y51, AP008230

SPOTS_45710A15

SPOTS 45710A130

SPOTS $45710 A 154$

SPOTS 45710A155

uncultured microorganism, DQ530618

- SPOTS_45706A53

SPOTS 45710A131

unculture d bacterium, FJ395132

- SPOTS 45712A141

L SPOTS $45712 \mathrm{~A} 48$

SPOTS_45706A21

- uncultured bacterium, EF133824

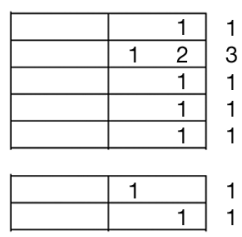

- uncultured microorganism, EF174723

SPOTS $45708 A 167$
SPOTS $45710 A 138$

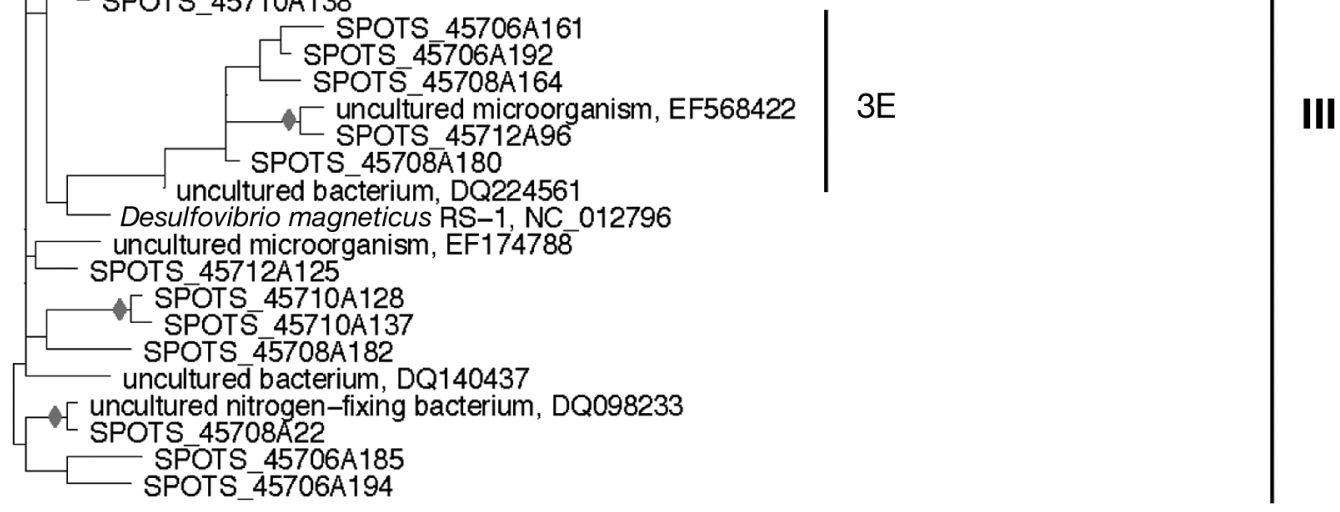

$3 \mathrm{~K}$

$1 \mathrm{~A}$

$\underline{0.10}$

Fig. 4. Neighbor-joining tree of partial nifH amino acid sequences (with GenBank accession numbers if available) recovered from depths of 5, 750 and $885 \mathrm{~m}$ at SPOTS (see Fig. 1 legend). Branch lengths were computed using the Kimura correction in ARB software, and bootstrapping was performed in MEGA 4.0. Nodes supported by bootstraps $>70 \%$ (1000 replicates) are marked with a diamond. The number and distribution of clones recovered for each phylotype is indicated in the table to the left of the tree. Clusters (I, II, and IV) and sub-clusters (1A, 1B, 3K, and 3E), according to nifH-based phylogeny, are shown to the right of the tree. Reference amino acid sequences are followed by GenBank accession nos

tive $\mathrm{N}^{*}$ and subsurface hypoxia, similar to the waters associated with the OMZs of the Pacific Ocean, which geochemical modeling has suggested may be hot spots of $\mathrm{N}_{2}$ fixation (Deutsch et al. 2007). Nitrogen fixation at the surface and chlorophyll-maximum depth was pri- marily (mean $80 \%$ ) associated with unicellular diazotrophs of $<10 \mu \mathrm{m}$ particle size (Table 1). This is higher than the contribution of unicellular diazotrophs to total $\mathrm{N}_{2}$ fixation at Stn ALOHA near Hawaii, USA, and in the tropical North Atlantic, which, in several 

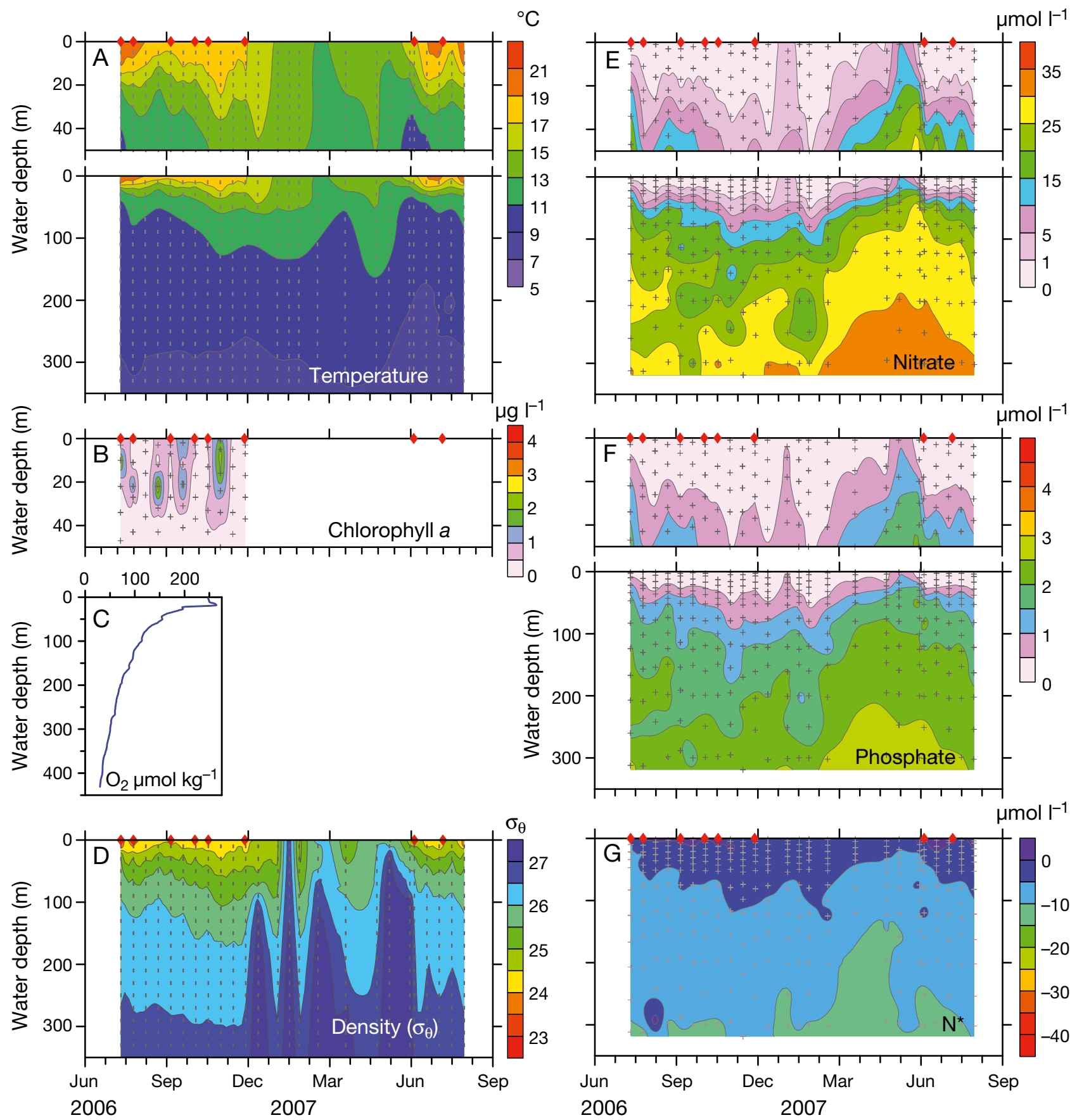

Fig. 5. Hydrographic and chemical properties over a period of $1 \mathrm{yr}$ at SMBO (see Fig. 1 legend). Details are given in the legend of Fig. 2; in Fig. 5, the sample profile for dissolved oxygen is from 11 Jul 2006

studies, ranged from 3 to 64 \% (Dore et al. 2002, Falcón et al. 2004, Grabowski et al. 2008). However, in the eastern temperate North Pacific, at the same latitude as our coastal site but in the open ocean, nanoplankton were responsible for nearly $100 \%$ of the measured $\mathrm{N}_{2}$ fixation (Needoba et al. 2007).

Nitrogen fixation rates attributable to nanoplankton at our sites averaged near the high end of the range of rates previously measured in the tropical Pacific and Atlantic Oceans. The mean surface $\mathrm{N}_{2}$ fixation rate by nanoplankton at SPOTS was $5.5 \mu \mathrm{mol} \mathrm{m}{ }^{-3} \mathrm{~d}^{-1}$ (maximum $35 \mu \mathrm{mol} \mathrm{m} \mathrm{m}^{-3} \mathrm{~d}^{-1}$ ), significantly higher than the average of ca. $0.3 \mu \mathrm{mol} \mathrm{m} \mathrm{m}^{-3} \mathrm{~d}^{-1}$ measured at Stn ALOHA (Dore et al. 2002) and in the temperate North Pacific (Needoba et al. 2007), and also higher than the maximum rate of $3.6 \mu \mathrm{mol} \mathrm{m} \mathrm{m}^{-3} \mathrm{~d}^{-1}$ measured in 


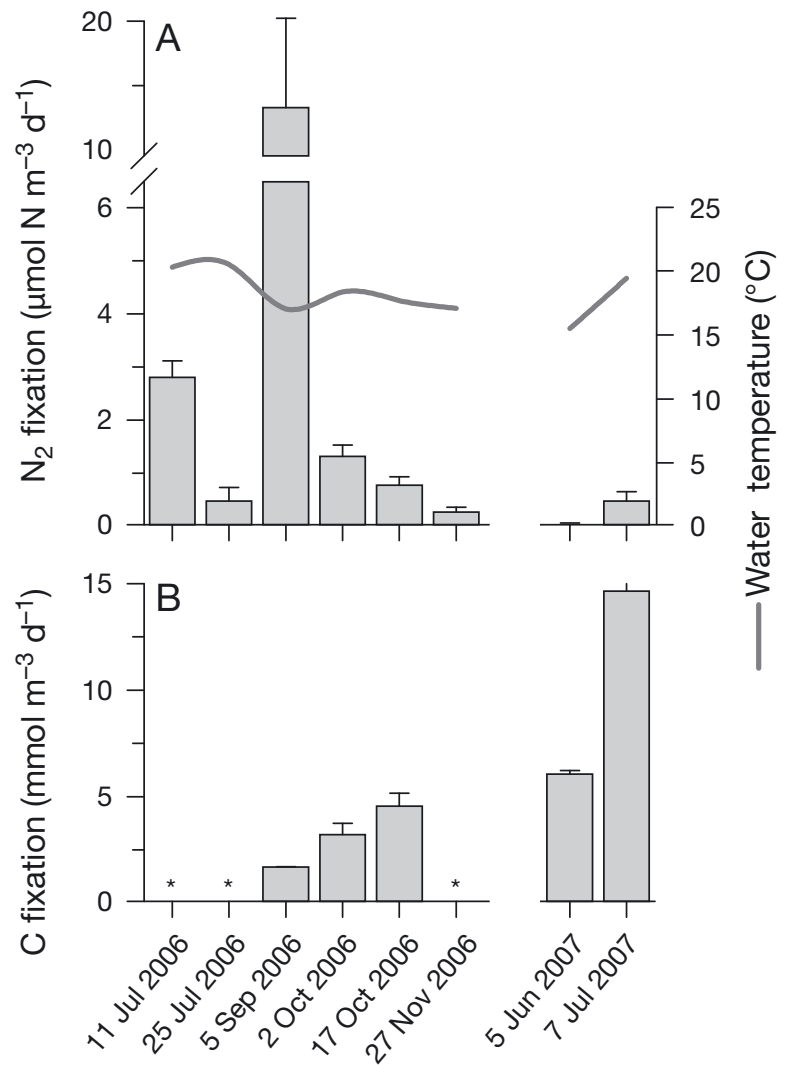

Fig. 6. (A) Nitrogen fixation and (B) carbon fixation in surface waters at SMBO (see Fig. 1 legend). Surface water temperature is indicated by the gray lines in panel A. An asterisk $\left({ }^{*}\right)$ indicates no data for that date. Error bars are SE

several tropical sites (Zehr et al. 2001, Dore et al. 2002, Montoya et al. 2004, Falcón et al. 2004, Holl et al. 2007, Grabowski et al. 2008). However, our maximum rates from the Southern California Bight (36 $\mu \mathrm{mol} \mathrm{m} \mathrm{m}^{-3} \mathrm{~d}^{-1}$ ) were similar to the rates reported by Montoya et al. (2004) from a transect across the eastern North Pacific at ca. $30^{\circ} \mathrm{N}$ latitude, which ranged up to $44 \mu \mathrm{mol} \mathrm{m} \mathrm{m}^{-3} \mathrm{~d}^{-1}$. Only results from a transect across the northern coast of Australia (maximum $1490 \mu \mathrm{mol} \mathrm{m} \mathrm{m}^{-3} \mathrm{~d}^{-1}$ ) were significantly higher than our findings (Montoya et al. 2004). The areal rates of photic zone $\mathrm{N}_{2}$ fixation that we measured in the Southern California Bight averaged $98 \mu \mathrm{mol} \mathrm{m} \mathrm{m}^{-2}$ $\mathrm{d}^{-1}$, within the range reported earlier for Trichodesmium using the acetylene reduction technique (reviewed in Montoya et al. 2004).

Our results support the significance of nanoplankton in $\mathrm{N}_{2}$ fixation in cooler subtropical and temperate waters $\left(<25^{\circ} \mathrm{C}\right)$. Furthermore, it confirms earlier indications that these cooler regions support populations of UCYN-A, in contrast to the Trichodesmium populations found in warmer waters, and is the first report of this diazotroph from the Southern California Bight. Our findings also agree with previous reports of UCYN-A in waters with elevated nitrate levels (e.g. Needoba et al. 2007, Rees et al. 2009, Moisander et al. 2010), again in contrast to Trichodesmium. The emerging picture is of a wider latitudinal range for pelagic $\mathrm{N}_{2}$ fixation than has been assumed, particularly for the less temperature- and nitrate-sensitive nanoplankton, which may play a greater role than colonial diazotrophs in temperate waters.

\section{Nitrogen fixation in the hypoxic water column}

We also detected $\mathrm{N}_{2}$ fixation within the hypoxic, high-nitrate waters of the San Pedro basin at depths of 500 and $885 \mathrm{~m}$. To our knowledge these represent the deepest $\mathrm{N}_{2}$ fixation measurements reported yet and the only ones from hypoxic waters. $\mathrm{N}_{2}$ fixation was significantly greater than zero in 12 out of 22 samples in which $\mathrm{N}_{2}$ fixation was measured (Fig. 3). Although these rates were lower than our photic-zone rates $\left(<0.3 \mu \mathrm{mol} \mathrm{m}{ }^{-3} \mathrm{~d}^{-1}\right)$, they were similar to rates reported earlier from surface waters at Stn ALOHA near Hawaii (Zehr et al. 2001, Dore et al. 2002, Falcón et al. 2004, Montoya et al. 2004, Codispoti 2007, Grabowski et al. 2008) and to a site in the eastern subtropical North Pacific (Needoba et al. 2007). Further, when integrated over the water column (from the chlorophyll-maximum depth to the bottom), they may contribute as much as $55 \mu \mathrm{mol} \mathrm{N} \mathrm{m}{ }^{-2} \mathrm{~d}^{-1}$, ca. one-third of the total estimated areal $\mathrm{N}_{2}$ fixation rate $\left(150 \mu \mathrm{mol} \mathrm{N} \mathrm{m}^{-2} \mathrm{~d}^{-1}\right)$ for this site. Our results within the hypoxic basins of the Southern California Bight were in contrast to other studies that measured $\mathrm{N}_{2}$ fixation at depth, which found that nearly all of the areal $\mathrm{N}_{2}$ fixation took place near the surface (Falcón et al. 2004, Holl et al. 2007, Needoba et al. 2007). $\mathrm{N}_{2}$ fixation took place in the hypoxic waters of our study despite nitrate concentrations $>32 \mu \mathrm{mol} \mathrm{l}^{-1}$. However, the Basin waters were deficient in nitrate relative to phosphate, with strongly negative $\mathrm{N}^{*}$ values ranging from -15 to -42 (Fig. 2). Particles $<10 \mu \mathrm{m}$ in size always accounted for $>87 \%$ of the hypoxic $\mathrm{N}_{2}$ fixation, and as these particles likely have very low sinking rates $\left(<1 \mathrm{~m} \mathrm{~d}^{-1}\right.$; Bienfang 1985), any phototrophic diazotrophs sinking from the mixed layer would likely have exhausted their energy resources by the time they reached these depths.

Phylogenetic characterizations of the deep hypoxic nanoplanktonic nifH gene revealed an assemblage of Clusters I and III heterotrophic diazotrophs. Previous studies have reported diverse heterotrophic, and in some cases anaerobic, nifH sequences from abyssopelagic waters (e.g. Hewson et al. 2007), and although in addition to detecting nifH sequences-our study 
measured $\mathrm{N}_{2}$ fixation rates directly - it is still unclear which heterotrophic diazotrophs might be responsible for the measured rates. The nested PCR approach necessary to amplify low-abundance nifH from the marine environment can be vulnerable to contamination (see discussion in Turk et al. 2011, and references therein). Although none of the sequences recovered from SPOTS were closely related to known contaminants, it is virtually impossible to identify a contaminant based on sequence alone. More quantitative molecular methods (e.g. qPCR) will be required to determine which of these phylotypes are ecologically relevant. The results from the present study represent a first step in investigating which heterotrophic diazotrophs are actively fixing $\mathrm{N}_{2}$ in deep hypoxic waters at SPOTS.

\section{Controls on $\mathrm{N}_{2}$ fixation}

Relatively few measurements of $\mathrm{N}_{2}$ fixation have been made in subtropical or temperate waters. While our coastal measurements at $34^{\circ} \mathrm{N}$ latitude were significantly higher than those made at the same latitude in the open Pacific (Needoba et al. 2007), they were similar to measurements of total $\mathrm{N}_{2}$ fixation made in the English Channel (maximum $20 \mu \mathrm{mol} \mathrm{m}^{3} \mathrm{~d}^{1}$; Rees et al. 2009). The high $\mathrm{N}_{2}$ fixation rates measured in our study, as well as in the English Channel, confirm that the assumption in global $\mathrm{N}$ budgets that $\mathrm{N}_{2}$ fixation is significant only in waters with surface temperatures $>20^{\circ} \mathrm{C}$ needs to be re-examined (Galloway et al. 2004, Holl et al. 2007, Needoba et al. 2007). The significance of the high nanoplanktonic $\mathrm{N}_{2}$ fixation rates in highlatitude, temperate waters that we report is corroborated by the recent report of wide distribution of $\mathrm{N}_{2}$ fixing cyanobacteria in similar latitudes and water temperatures (Moisander et al. 2010).

Contrary to expectations that $\mathrm{N}_{2}$ fixation should be maximal during summer stratification, when phytoplankton growth depletes surface water $\mathrm{N}$ and P (e.g. Dore et al. 2002, Falcón et al. 2004), we found the highest rates of nanoplanktonic $\mathrm{N}_{2}$ fixation during December and February (Fig. 3). This observation suggests that nanoplanktonic $\mathrm{N}_{2}$ fixation may play a significant role year-round, rather than being restricted to periods of intense stratification. In contrast to earlier studies that found a correlation between $\mathrm{PN}$ and $\mathrm{N}_{2}$ fixation (Dore et al. 2002), episodes of elevated $\mathrm{N}_{2}$ fixation were not associated with episodes of high PN at either SPOTS or SMBO (data not shown), nor was $\mathrm{N}_{2}$ fixation correlated with gross carbon fixation at SMBO (Fig. 6). These observations indicate that $\mathrm{N}_{2}$ fixation and overall production were uncoupled at our sites.

Our $3 \mathrm{yr}$ record of $\mathrm{N}_{2}$ fixation at SPOTS suggests that surface $\mathrm{N}_{2}$ fixation is often correlated with SST
(Fig. 3) However, the high $\mathrm{N}_{2}$ fixation rates measured in the winter of 2005 to 2006 are anomalous, because surface temperatures were low during this time. Neither can these anomalously high $\mathrm{N}_{2}$ fixation rates be explained by changes in any of the other hydrochemical parameters measured. The relationship of surface $\mathrm{N}_{2}$ fixation rates to SST at SPOTS also does not explain the 2-fold lower mean $\mathrm{N}_{2}$ fixation rates at $\mathrm{SMBO}$, because mean temperatures were lower at SMBO, while nitrate and phosphate concentrations were similar (Figs. $2 \& 4$ ). The factors controlling $\mathrm{N}_{2}$ fixation within the Southern California Bight, and particularly the winter $\mathrm{N}_{2}$ fixation peaks, remain unclear.

Additions of iron and phosphate to sea water during incubations at SMBO had no appreciable effect on $\mathrm{N}_{2}$ fixation rates (Fig. S2). Limitation of phytoplankton growth by iron has been reported for nearby sites in the California Current System (Firme et al. 2003, King $\&$ Barbeau 2007). However, the dissolved iron concentrations measured in these studies were $<0.46 \mathrm{nmol}^{-1}$, compared to the mean concentration of $1.8 \mathrm{mmol} \mathrm{l}^{-1}$ measured at SMBO (Mendez 2008). Similarly, $\mathrm{PO}_{4}{ }^{3-}$ concentrations at SPOTS and SMBO averaged $0.3 \mu \mathrm{M}$, which were greater than ambient concentrations where $\mathrm{PO}_{4}{ }^{3-}$ stimulation of $\mathrm{N}_{2}$ fixation has been observed (Mills et al. 2004, Grabowski et al. 2008). However, we did not eliminate possible co-limitation by $\mathrm{Fe}$ and $\mathrm{PO}_{4}{ }^{3-}$ (Mills et al. 2004).

Our study of $\mathrm{N}_{2}$ fixation rates within the Southern California Bight supports earlier observations that $\mathrm{N}_{2}$ fixation rates by nanoplankton can be high in temperate waters. Further, we report significant $\mathrm{N}_{2}$ fixation rates within deep, hypoxic waters with high concentrations of nitrate. Although these rates were much lower than at the surface, when integrated over the water column, they might contribute as much as one-third of the total areal rate of $\mathrm{N}_{2}$ fixation. These observations suggest that $\mathrm{N}_{2}$ fixation might also play a role within the large OMZs of the Pacific Ocean. It is possible that an expansion of the range of active pelagic $\mathrm{N}_{2}$ fixation into temperate and hypoxic waters may address the imbalance between denitrification and $\mathrm{N}_{2}$ fixation in scaled global estimates.

Acknowledgements. This work was funded by the University of University of Southern California (USC) Wrigley Institute for Environmental Studies and Soka University of America. D.G.C. also acknowledges the long-term support of the Ocean Sciences Division of the US National Science Foundation (NSF). The SMBO program was funded by the NSF, the Southern California Coastal Ocean Observatory System, and ETH Zürich. A Gordon and Betty Moore Foundation Marine Investigator Grant (to J.P.Z.) supported all molecular analyses. The authors thank J. Mendez, A. Knapp, W. Berelson, R. Shipe and J. Sohm for equipment contributions and many 
helpful discussions, as well as the Captains and crews of the RV 'Sea Watch' and the RV 'Seaworld'. We thank B. Jones and Z. Zheng (USC) for the SPOT nutrient analysis, A. Dickson (Scripps Institute of Oceanography) for the SMBO DIC and alkalinity analyses, and S. Sañudo-Wilhelmy (USC) for the iron analyses. We are also indebted to L. Codispoti and one anonymous reviewer for helpful comments and suggestions during review.

\section{LITERATURE CITED}

Berelson WM (1991) The flushing of two deep-sea basins, southern California borderland. Limnol Oceanogr 36: 1150-1166

Bienfang PK (1985) Size structure and sinking rates of various microparticulate constituents in oligotrophic Hawaiian waters. Mar Ecol Prog Ser 23:143-151

Capone DG, Zehr J, Paerl H, Bergman B, Carpenter EJ (1997) Trichodesmium, a globally significant marine cyanobacterium. Science 276:1221-1229

Capone DG, Burns JA, Montoya JP, Subramaniam A and others (2005) Nitrogen fixation by Trichodesmium spp.: an important source of new nitrogen to the tropical and subtropical North Atlantic Ocean. Global Biogeochem Cycles 19:GB2024

> Church MJ, Jenkins BD, Karl DM, Zehr JP (2005a) Vertical distributions of nitrogen-fixing phylotypes at Stn ALOHA in the oligotrophic North Pacific Ocean. Aquat Microb Ecol 38:3-14

Church MJ, Short CM, Jenkins BD, Karl DM, Zehr JP (2005b) Temporal patterns of nitrogenase gene (nifH) expression in the oligotrophic North Pacific Ocean. Appl Environ Microbiol 71:5362-5370

Codispoti LA (2007) An oceanic fixed nitrogen sink exceeding $400 \mathrm{Tg} \mathrm{N} \mathrm{a}{ }^{-1}$ vs the concept of homeostasis in the fixednitrogen inventory. Biogeosciences 4:233-253

Codispoti LA, Richards FA (1976) An analysis of the horizontal regime of denitrification in the eastern tropical North Pacific. Limnol Oceanogr 21:379-388

> Codispoti LA, Brandes JA, Christensen JP, Devol AH, Naqvi SWA, Paerl HW, Yoshinari T (2001) The oceanic fixed nitrogen and nitrous oxide budgets: moving targets as we enter the anthropocene? Sci Mar 65:85-105

Deutsch C, Gruber N, Key RM, Sarmiento JL, Ganachaud A (2001) Denitrification and $\mathrm{N}_{2}$ fixation in the Pacific Ocean. Global Biogeochem Cycles 15:483-506

> Deutsch C, Sarmiento JL, Sigman DM, Gruber N, Dunne JP (2007) Spatial coupling of nitrogen inputs and losses in the ocean. Nature 445:163-167

Dickson AG, Goyet C (eds) (1994) Handbook of methods for the analysis of the various parameters of the carbon dioxide system in sea water, version 2. ORNL/CDIAC-74, United States Department of Energy, Washington, DC

$>$ Dore JE, Brub JR, Tupas LM, Karl DM (2002) Seasonal and interannual variability in sources of nitrogen supporting export in the oligotrophic subtropical North Pacific Ocean. Limnol Oceanogr 47:1595-1607

Falcón LI, Carpenter EJ, Cipriano F, Bergman B, Capone DG (2004) $\mathrm{N}_{2}$ fixation by unicellular bacterioplankton from the Atlantic and Pacific Oceans: phylogeny and in situ rates. Appl Environ Microbiol 70:765-770

Firme GF, Rue EL, Weeks DA, Bruland KW, Hutchins DA (2003) Spatial and temporal variability in phytoplankton iron limitation along the California coast and consequences for $\mathrm{Si}, \mathrm{N}$, and $\mathrm{C}$ biogeochemistry. Global Biogeochem Cycles 17,1016, doi:10.1029/2001GB001824
Foster RA, Paytan A, Zehr JP (2009a) Seasonality of $\mathrm{N}_{2}$ fixation and nifH diversity in the Gulf of Aqaba (Red Sea). Limnol Oceanogr 54:219-233

> Foster RA, Subramaniam A, Zehr JP (2009b) Distribution and activity of diazotrophs in the Eastern Equatorial Atlantic. Environ Microbiol 11:741-750

> Galloway JN, Dentener FJ, Capone DG, Boyer EW and others (2004) Nitrogen cycles: past, present, and future. Biogeochemistry 70:153-226

Goebel NL, Turk KA, Achilles KM, Paerl RW and others (2010) Abundance and distribution of major groups of diazotrophic cyanobacteria and their potential contribution to $\mathrm{N}_{2}$ fixation in the tropical Atlantic Ocean. Environ Microbiol 12:3272-3289

> Grabowski MNW, Church MJ, Karl DM (2008) Nitrogen fixation rates and controls at Stn ALOHA. Aquat Microb Ecol 52:175-183

Grasshoff K, Ehrdardt M, Kremling K, Anderson LG (1999) Methods of seawater analysis. Wiley, Hoboken, NJ

Gruber N (2004) The dynamics of the marine nitrogen cycle and atmospheric $\mathrm{CO}_{2}$. In: Oguz T, Follows N (eds) Carbon climate interactions. Kluwer, Dordrecht, p 97-148

Gruber N, Sarmiento JL (1997) Global patterns of marine nitrogen fixation and denitrification. Global Biogeochem Cycles 11:235-266

Hamersley MR, Lavik G, Woebken D, Rattray JE and others (2007) Anaerobic ammonium oxidation in the Peruvian oxygen minimum zone. Limnol Oceanogr 52:923-933

> Hewson I, Moisander PH, Achilles KM, Carlson CA and others (2007) Characteristics of diazotrophs in surface to abyssopelagic waters of the Sargasso Sea. Aquat Microb Ecol 46:15-30

Holl C, Montoya J (2005) Interactions between nitrate uptake and nitrogen fixation in continuous cultures of the marine diazotroph, Trichodesmium. J Phycol 41:1178-1183

Holl CM, Waite AM, Pesant S, Thompson PA, Montoya JP (2007) Unicellular diazotrophy as a source of nitrogen to Leeuwin Current coastal eddies. Deep-Sea Res II 54: 1045-1054

Johnson KM, Wills KD, Butler DB, Johnson WK, Wong CS (1993) Coulometric total carbon dioxide analysis for marine studies: maximizing the performance of an automated gas extraction system and coulometric detector. Mar Chem 44:167-187

Karl D, Michaels A, Bergman B, Capone D and others (2002) Dinitrogen fixation in the world's oceans. Biogeochemistry 57/58:47-98

King AL, Barbeau K (2007) Evidence for phytoplankton iron limitation in the southern California Current System. Mar Ecol Prog Ser 342:91-103

Leinweber A, Gruber N, Frenzel GE, Friederich GE, Chavez FP (2009) Diurnal carbon cycling in the surface ocean and lower atmosphere of Santa Monica Bay, California. Geophys Res Lett 36,L08601, doi:10.1029/2008GL037018

Mendez J (2008) Iron and manganese in the ocean: atmospheric input by dust and ocean time series. PhD thesis, California Institute of Technology, Pasadena, CA

Mills MM, Ridame C, Davey M, La Roche J, Gelder RJ (2004) Iron and phosphorus co-limit nitrogen fixation in the eastern tropical North Atlantic. Nature 429:292-294

Moisander PH, Beinart RA, Voss M, Zehr JP (2008) Diversity and abundance of diazotrophic microorganisms in the South China Sea during intermonsoon. ISME J 2: 954-967

Moisander PH, Beinart RA, Hewson I, White AE and others (2010) Unicellular cyanobacterial distributions broaden the oceanic $\mathrm{N}_{2}$ fixation domain. Science 327:1512-1514 
Montoya JP, Holl CM, Zehr JP, Hansen A, Villareal TA, Capone DG (2004) High rates of $\mathrm{N}_{2}$ fixation by unicellular diazotrophs in the oligotrophic Pacific Ocean. Nature 430:1027-1031

Mulholland MR, Ohki K, Capone DG (2001) Nutrient controls on nitrogen uptake and metabolism by natural populations and cultures of Trichodesmium (Cyanobacteria). J Phycol 37:1001-1009

Needoba JA, Foster RA, Zehr JP, Johnson KS (2007) Nitrogen fixation by unicellular diazotrophic cyanobacteria in the temperate oligotrophic North Pacific Ocean. Limnol Oceanogr 52:1317-1327

Nezlin NP, Li BL (2003) Time-series analyis of remote-sensed chlorophyll and environmental factors in the Santa Monica-San Pedro Basin off Southern California. J Mar Syst 39:185-202

Olson JB, Litaker RW, Paerl HW (1999) Ubiquity of heterotrophic diazotrophs in marine microbial mats. Aquat Microb Ecol 19:29-36

Redfield A, Ketchum BH, Richards FA (1963) The influence of organisms on the composition of sea water. In: Hill M (ed) The sea, Vol 2. Academic Press, New York, NY

Editorial responsibility: Patricia Glibert,

Cambridge, Maryland, USA
Rees AP, Gilbert JA, Kelly-Gerreyn BA (2009) Nitrogen fixation in the western English Channel (NE Atlantic Ocean). Mar Ecol Prog Ser 374:7-12

Schloss PD, Handelsman J (2005) Introducing DOTUR, a computer program for defining operational taxonomic units and estimating species richness. Appl Environ Microbiol 71:1501-1506

Tamura K, Dudley J, Nei M, Kumar S (2007) MEGA4: molecular evolutionary genetics analysis (MEGA) software version 4.0. Mol Biol Evol 24:1596-1599

Turk KA, Rees A, Zehr JP, Pereira N and others (2011) Nitrogen fixation and nitrogenase (nifH) expression in tropical waters of the eastern North Atlantic. ISME J, doi:10.1038/ ismej.2010.205

Zehr JP, Waterbury JB, Turner PJ, Montoya JP and others (2001) Unicellular cyanobacteria fix $\mathrm{N}_{2}$ in the subtropical North Pacific Ocean. Nature 412:635-638

Zehr JP, Crumbliss LL, Church MJ, Omoregie EO, Jenkins BD (2003) Nitrogenase genes in PCR and RT-PCR reagents: implications for studies of diversity of functional genes. Biotechniques 35:996-1005

Submitted: June 10, 2010; Accepted: January 13, 2011 Proofs received from author(s): April 13, 2011 